УДК 615.2:612.06

DOI: $10.26435 /$ UC.V0I4(33).394

\author{
М.Ю. Осканова ${ }^{1}$, В.Д. Слепушкин ${ }^{2}$, А.Н. Колесников ${ }^{3}$, В.В. Гончаров ${ }^{3}$,Р.В. Скоробогатый \\ ${ }_{1}^{1}$ Республиканская клиническая больница Республики Ингушетия, Назрань, Россия \\ ${ }^{2}$ ФГБОУ ВПО «Северо-осетинская государственная медицинская академия» Минздрава России, Владикавказ, Россия \\ зГОО ВПО «Донецкий национальный медицинский университет имени М. Горького», Донецк
}

\title{
КИСЛОРОДНЫЙ ОБМЕН ГОЛОВНОГО МОЗГА И ГЛУБИНА СЕДАЦИИ ПРИ ПРИМЕНЕНИИ РАЗЛИЧНЫХ МЕДИКАМЕНТОВ У КРИТИЧЕСКИХ БОЛЬНЫХ
}

В комплексе интенсивной терапии, наряду с поддержанием витальных функций, важное место занимает адекватная седация больных [1]. Одним из показаний для проведения седации критическим больным является снижение потребления кислорода тканью мозга [2]. В литературе лишь в общих чертах сообщается, что основные препараты, используемые для седации, - тиопентал натрия, диазепама, пропофол снижают потребление кислорода тканями на 3050\% [3], но не указываются четкие границы снижения потребления кислорода в зависимости от дозировки препарата.

\section{ЦЕЛЬИССЛЕДОВАНИЯ}

Определить степень экстракции кислорода мозгом в процессе проведения седации критических больных при инфузии тиопентала натрия, диазепама, пропофола.

\section{МАТЕРИАЛ И МЕТОДЫ}

В работу включены 3 группы больных, которые были разделены по типу инфузируемого препарата: тиопентал натрия (16 больных), диазепама (14 больных), пропофол (14 больных), стандартизированные по полу (мужчины), возрасту $(34,7 \pm 2,2$ года) и характеру травмы (множественная скелетная травма). Степень тяже-

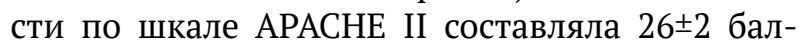
ла. Больные находились на ИВЛ вентиляторами INTERMED PLUS в режиме SIMV. Первая группа больных получала инфузию тиопентала натрия в дозе 1000 мкг/кг/ч (2 г в сутки), вторая группа - инфузию диазепама в дозе 75 мкг/кг/ч (30 мг в сутки), третья группа - инфузию пропофола в дозе 1000 мкг/кг/ч (400 мг в сутки).

Оценка параметров степени экстракции кислорода мозгом проводилась с первых по пятые сутки. Уровень седации оценивали BISспектральным методом (приставка BISx к монитору DACH5000) в фиксированное время -
12.00 ч. О степени экстракции кислорода головным мозгом $\left(\mathrm{ERO}_{2}\right.$ в \%) судили по разнице между насыщением артериальной (методом пульсоксиметрии) и венозной (методом церебральной оксиметрии) крови кислородом. Использовали одинаковый уровень седации (от 37 до 40 баллов BIS-индекса), необходимый больным для синхронизации с респиратором, проведения диагностических и лечебных манипуляций, что соответствует седативному эффекту по шкале Ramsey в пределах 4-5 баллов.

Статистическая обработка полученных данных проводилась с использованием критерия Вилкоксона (непараметрический метод оценки изменений количественного показателя на 2-х этапах зависимых выборок) в программе STATISTICA 10.

\section{РЕЗУЛЬТАТЫ ИОБСУЖДЕНИЕ}

Степень экстракции кислорода мозговой тканью была неоднородной у больных трех групп (см. табл.). В 1 группе пациентов, получавших инфузию тиопентала натрия, на 4-е и 5-е сутки седативной терапии экстракция кислорода мозговой тканью снижалась на 30-35\% $(\mathrm{p}<0,05)$ по сравнению с первыми сутками и была почти в 2 раза меньше, чем у больных 2-й и 3-й групп. Во 2 группе больных, которым проводили инфузию диазепама, на 5-е сутки экстракция кислорода мозговой тканью повышалась на $14 \%$ ( $<<0,05)$. В 3 группе пациентов, получавших постоянную инфузию пропофола, степень экстракции кислорода мозговой тканью на протяжении всех пяти суток наблюдения оставалась неизменной. Следует отметить, что индексированный показатель степени доставки кислорода колебался в

(c) М.Ю. Осканова, В.Д. Слепушкин, А.Н. Колесников, B.В. Гончаров, Р.В. Скоробогатый, 2019 (C) Университетская Клиника, 2019 
незначительных пределах во всех группах больных.

Но обращали на себя внимание два обстоятельства:

1. При длительной (в течение 5-ти суток) инфузии тиопентала натрия седативный эффект, оцениваемый по уровню BIS-индекса, углублялся статистически значимо на 4-е и 5-е сутки при одинаковой величине суточной дозы препарата.

2. При постоянной суточной инфузии диазепама на 5-е сутки регистрировалось возрастание BIS-индекса глубины седации. Инфузия пропофола обеспечtивала постоянную глубину седации на протяжении всех пяти суток наблюдения.
Следовательно, изменение степени экстракции кислорода у больных первой и второй групп являлось следствием нарушения потребления кислорода, а не его доставки. У пациентов 1 группы с инфузией тиопентала натрия на 4-е и 5-е сутки почти в 2 раза возрастал уровень лактата в венозной крови.

Из приведенных результатов следует, что под влиянием длительной инфузии тиопентала натрия в одинаковой суточной дозе на 4-е и 5-е сутки происходит снижение потребления кислорода тканью мозга, развивается гипоксия, о чем свидетельствует нарастание уровня лактата в пробах венозной крови, полученной из яремной вены [3]. Это приводит к неконтролируемому углублению уровня седации пациентов, что

Показатели экстракции кислорода мозговой тканью $\left(\mathrm{ERO}_{2}\right)$, индекса доставки кислорода $\left(\mathrm{DO}_{2} \mathrm{I}\right)$,

Таблица. содержание лактата в венозной крови и уровень седации больных по данным BIS-спектрального индекса $(\mathrm{M} \pm \mathrm{m})$

\begin{tabular}{|c|c|c|c|c|c|}
\hline \multirow{2}{*}{ Группа } & \multicolumn{5}{|c|}{ Сутки проведения седативной терапии } \\
\hline & 1 & 2 & 3 & 4 & 5 \\
\hline \multicolumn{6}{|c|}{ ERO2(\%) } \\
\hline 1 & $12,2 \pm 1,1$ & $12,0 \pm 1,0$ & $10,2 \pm 0,8$ & $9,1 \pm 0,6^{*}$ & $8,4 \pm 0,6^{*}$ \\
\hline 2 & $16,3 \pm 1,3$ & $17,3 \pm 1,3$ & $19,1 \pm 1,1$ & $19,0 \pm 1,0$ & $20,7 \pm 1,1^{*}$ \\
\hline 3 & $15,7 \pm 1,0$ & $15,9 \pm 1.1$ & $15,8 \pm 1,1$ & $16,0 \pm 1,3$ & $15,8 \pm 1,0$ \\
\hline \multicolumn{6}{|c|}{ DO2I (мл/мин/м2) } \\
\hline 1 & $719,4 \pm 25,1$ & $726,3 \pm 25,3$ & $721,3 \pm 26,1$ & $728,4 \pm 25,9$ & $724,8 \pm 25,9$ \\
\hline 2 & $721,5 \pm 27,1$ & $726,3 \pm 30,2$ & $720,4 \pm 28,3$ & $724,5 \pm 29,4$ & $721,5 \pm 29,6$ \\
\hline 3 & $726,3 \pm 29,3$ & $719,7 \pm 30,1$ & $724,3 \pm 30,2$ & $720,3 \pm 29,4$ & $721,4 \pm 29,8$ \\
\hline \multicolumn{6}{|c|}{ Лактат (ммоль/л) } \\
\hline 1 & $1,30 \pm 0,12$ & $1,41 \pm 0,11$ & $1,49 \pm 0,11$ & $2,31 \pm 0,12^{*}$ & $2,49 \pm 0,14^{*}$ \\
\hline 2 & $1,11 \pm 0,11$ & $1,14 \pm 0,11$ & $1,18 \pm 0,10$ & $1,20 \pm 0,10$ & $1,14 \pm 0,10$ \\
\hline 3 & $1,07 \pm 0,10$ & $1,15 \pm 0,10$ & $1,17 \pm 0,09$ & $1,21 \pm 0,10$ & $1,13 \pm 0,11$ \\
\hline \multicolumn{6}{|c|}{ Уровень седации } \\
\hline 1 & $37,4 \pm 2,1$ & $36,3 \pm 2,0$ & $34,3 \pm 2,0$ & $28,1 \pm 1,9 *$ & $24,1 \pm 1,6^{*}$ \\
\hline 2 & $40,3 \pm 3,2$ & $40,1 \pm 3,4$ & $39,1 \pm 3,6$ & $44,1 \pm 3,1$ & $48,1 \pm 2,2 *$ \\
\hline 3 & $37,3 \pm 3,0$ & $37,1 \pm 2,5$ & $36,9 \pm 2,8$ & $36,8 \pm 2,6$ & $36,9 \pm 2,7$ \\
\hline
\end{tabular}

Примечание.* - статистически значимое различие по отношению к первым суткам (p<0,05). 
может создать трудности при переводе больных на самостоятельное дыхание, а также провоцировать органную дисфункцию.

При проведении продленной седации с использованием диазепама регистрировалось, наоборот, увеличение потребления кислорода тканью мозга с одновременным снижением уровня седации на 5-е сутки. Данное обстоятельство требовало увеличения доз диазепама для седации, что в дальнейшем могло привести к проблеме со стороны восстановления ментальных функций [4].

При постоянной инфузии пропофола на протяжении пяти суток не отмечалось значимых колебаний со стороны экстракции кислорода мозговой тканью, а также глубины седации пациентов.

Из полученных результатов в отношении длительной инфузии постоянных доз тиопентала натрия пациентам с целью седации можно сделать практический вывод, что на четвертыепятые сутки дозы препарата следует уменьшать для предотвращения развития тканевой гипоксии и функциональных нарушений органов и систем, что является следствием кардиодепрессивного эффекта тиопентала натрия [6].

\section{В Ы В $О$ д Ы}

1. При проведении длительной седативной терапии тиопенталом натрия в постоянной суточной дозе на 4-е и 5-е сутки снижается потребление кислорода мозговой тканью, развивается гипоксия, что сопровождается неконтролируемым усугублением степени седации пациентов.

2. Длительная и постоянная инфузия диазепама на 5-е сутки сопровождается увеличением экстракции кислорода головным мозгом и одновременным повышением величины BlSиндекса, то есть уменьшением глубины седации.

3. Постоянная инфузия пропофола не изменяет величину экстракции кислорода головным мозгом и глубину седации.

\section{М.Ю. Осканова 1 В.Д. Слепушкин ${ }^{2}$, А.Н. Колесников ${ }^{3}$, В.В. Гончаров ${ }^{3}$ Р.В. Скоробогатый}

${ }^{1}$ Республиканская клиническая больница Республики Ингушетия, Назрань, Россия

${ }^{2}$ ФБОУ ВПО «Северо-Осетинская государственная медицинская академия» Минздрава России, Владикавказ, Россия

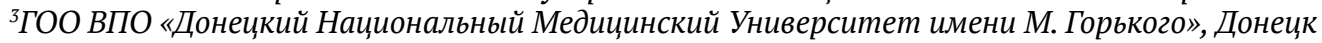

\section{КИСЛОРОДНЫЙ ОБМЕН ГОЛОВНОГО МОЗГА И ГЛУБИНА СЕДАЦИИ ПРИ ПРИМЕНЕНИИ РАЗЛИЧНЫХ МЕДИКАМЕНТОВ У КРИТИЧЕСКИХ БОЛЬНЫХ}

Обследовано 44 больных с множественной скелетной травмой, которым проводилась ИВЛ и седативная терапия в виде постоянной инфузии тиопентала натрия, диазепама или пропофола на протяжении 5 суток. У всех больных BIS-индекс не более 40. Оценивалась доставка кислорода и экстракция кислорода мозговой тканью. Установлено, что при проведении седативной терапии тиопенталом натрия на 4-е и 5-е сутки уменьшается степень экстракции кислорода мозгом, развивается гипоксия с нарастанием уровня лак- тата, одновременно понижается индекс биспектрального анализа, то есть неконтролируемо усугубляется степень седации. При инфузии диазепама, наоборот, на 5-е сутки регистрируется повышение экстракции кислорода мозгом и повышается степень седации. При инфузии пропофола на протяжении всех 5 суток степень экстракции кислорода мозговой тканью и уровень седации остаются постоянными.

Ключевые слова: критические больные, седация, обмен кислорода.

\section{M.Ju. Oskanova ${ }^{3}$, V.D. Slepushkin ${ }^{1}$, A.N. Kolesnikov², V.V. Goncharov' ${ }^{2}$ R.V. Skorobogatyj ${ }^{2}$}

${ }^{1}$ Republican Clinical Hospital of the Republic of Ingushetia, Nazran, Russia

${ }^{2}$ FSFEI HPE «Northen Ossetian State Academy of Medicine» Ministry of Health of Russia, Vladikavkaz, Russia

${ }^{3}$ SEI HPE «M. Gorky Donetsk National Medical University», Donetsk

\section{OXYGEN EXCHANGE OF THE BRAIN AND DEPTH OF SEDATION WHEN USING VARIOUS MEDICINES IN CRITICAL PATIENTS}

44 patients with multiple orthopedic trauma who underwent mechanical ventilation and sedative therapy in the form of continuous infusion of thiopental sodium, diazepam or propofol for 5 days were examined. In all patients, the BIS index is not more than 40. Oxygen delivery and oxygen extraction by brain tissue were evaluat- ed. It was found that during sedative therapy with thiopental sodium on days 4 and 5 , the degree of oxygen extraction by the brain decreases, hypoxia develops with increasing levels of lactate, and the bispectral analysis index decreases, that is the degree of sedation is uncontrollably exacerbated. With diazepam infusion, on the con- 
trary, on day 5 , an increase in oxygen extraction by the brain is recorded and the degree of sedation increases. With propofol infusion throughout all 5 days, the degree of oxygen extraction by the brain tissue and the level of sedation remain constant.

Key words: critical patients, sedation, oxygen exchange.

\section{ЛИТЕРАТУРА}

1. Заболотских И.Б., Песнях Е.В. Седация в интенсивной терапии. Петрозаводск: «ИнтелТек»; 2007. 78.

2. Rhoney D.H., Parker D.J. Use of sedative and analgesic agents in neurotrauma patients: effects on cerebral physiology. Neurol. Res. 2001; 23: 237-259.

3. Николаенко Э.М. Седация диприваном больных с поражениями головного мозга: влияние на церебральное кровообращение и метаболизм. Вестник интенсивной терапии. $1995 ; 5: 18-22$.

4. Finkielman J.D. Randomized trial of light versus deep sedation on mental health after critical illness. Crit. Care Med. 2010; 38:349.

5. Van Beest P. et al. Lactate: an unusually sensitive parameter of ensuing organ failure? Crit. Care Med. 2010; 38: 337.

6. Осканова М.Ю. Пути оптимизации седативной терапии у пациентов, находящихся в критическом состоянии, с позиций хронофизиологии: дис... доктора мед. наук. Назрань; 2019. 166.

\section{REFERENCES}

1. Zabolotskikh I.B., Pesnyakh E.V. Sedatsiya v intensivnoi terapii. Petrozavodsk: «IntelTek»; 2007. 78 (in Russian).

2. Rhoney D.H., Parker D.J. Use of sedative and analgesic agents in neurotrauma patients: effects on cerebral physiology. Neurol. Res. 2001; 23: 237-259.

3. Nikolaenko E.M. Sedatsiya diprivanom bol'nykh s porazheniyami golovnogo mozga: vliyanie na tserebral'noe krovoobrashchenie i metabolizm. Vestnik intensivnoi terapii. 1995; 5: 18-22 (in Russian).

4. Finkielman J.D. Randomized trial of light versus deep sedation on mental health after critical illness. Crit. Care Med. 2010; 38:349.

5. Van Beest R. et al. Lactate: an unusually sensitive parameter of ensuing organ failure? Crit. Care Med. 2010; 38: 337.

6. Oskanova M.Yu. Puti optimizatsii sedativnoi terapii u patsientov, nakhodyashchikhsya $\mathrm{v}$ kriticheskom sostoyanii, s pozitsii khronofiziologii: dis... doktora med. nauk. Nazran'; 2019. 166 (in Russian). 